\title{
Learning object development for the Anatomy teaching in Nursing
}

\author{
Desenvolvimento de objeto de aprendizagem para o ensino de Anatomia em Enfermagem
}

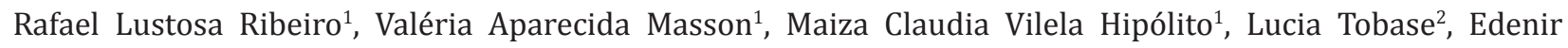
Aparecida Sartorelli Tomazini ${ }^{2}$, Heloísa Helena Ciqueto Peres ${ }^{2}$

Objective: to describe the development of the learning object called "Disciplinary Complement of Anatomy" for the teaching and learning of Anatomy subject. Methods: this is a methodological study on the construction of the learning object to complement the studies in the subject, using the Analysis, Design, Development, Implementation and Evaluation model in the instructional design. Results: as a virtual class, the learning object was developed according to the steps of Analysis, Design, Development, Implementation, and Evaluation and it was implemented in Prezi ${ }^{\circledR}$ as a virtual environment. Conclusion: the virtual class was set up in an innovative strategy that allowed autonomy in learning and managing technologies in the educational process, articulating ethics in the study of Anatomy.

Descriptors: Education, Distance; Anatomy; Information Technology; Video-Audio Media; Education, Nursing.

Objetivo: descrever o desenvolvimento do objeto de aprendizagem denominado "Complemento Disciplinar de Anatomia" para o ensino e a aprendizagem da disciplina Anatomia. Métodos: estudo metodológico sobre a construção do objeto de aprendizagem para complementação dos estudos na disciplina, utilizando o modelo Analysis, Design, Development, Implementation e Evaluation no design instrucional. Resultados: o objeto de aprendizagem, como aula virtual, foi desenvolvido conforme as etapas do Analysis, Design, Development, Implementation e Evaluation e implementada no Prezi ${ }^{\circledR}$, como ambiente virtual. Conclusão: a aula virtual configurou-se em estratégia inovadora que possibilitou a autonomia no aprendizado e manejo das tecnologias no processo educativo, articulando a ética no estudo da Anatomia.

Descritores: Educação à Distância; Anatomia; Tecnologia da Informação; Mídia Audiovisual; Educação em Enfermagem.

\footnotetext{
${ }^{1}$ Universidade Estadual de Campinas. Campinas, SP, Brazil.

${ }^{2}$ Universidade de São Paulo. São Paulo, SP, Brazil. 


\section{Introduction}

The National Curricular Guidelines of the undergraduate course in Nursing explain the curricular matrix, whose essential contents of the course integrate thematic areas of the biological sciences, about Human Anatomy, Physiology, Pharmacology, Pathology, among others ${ }^{(1)}$. Considered a descriptive science, the study of Anatomy is associated with several new terms, names of structures, processes of the human body and it requires strategies to facilitate the learning of different contents.

In general, it is presented at the beginning of the undergraduate course and students often feel overwhelmed by the diversity and complexity of the content to be assimilated ${ }^{(2)}$. As a compulsory subject, given in the basic cycle in health care courses, it requires special attention since in addition to the complexity of the contents, the characteristics of the students, the maturity in the approach to the subject and the teaching strategies influence its good use ${ }^{(2)}$. Also, the problem of failure and avoidance due to difficulties in this subject is a worrying reality, experienced by many who enter the courses, including Nursing ${ }^{(3)}$.

For Human Anatomy teaching, institutions commonly use institutions of deceased people, according to Federal Law 8.501/1992, from donations or not sought by friends or relatives ${ }^{(4)}$. Sometimes, in the first contacts, in the laboratory exposition, without previous preparation, it produces unpredictable impacts on students, from the risks of emotional and traumatic disturbances in front of this practice and other health damages by contact with highly toxic chemical substances, used in the maintenance and preservation of the body or anatomical piece or contamination by cadaveric pathogens, previously present in the body or acquired after death ${ }^{(5)}$.

In this context, the Anatomy approach has singular aspects regarding ethical issues, the process of teaching and coping students in the learning situation, and the shortage of qualified teachers ${ }^{(6)}$.
In general, traditional methods involve theoretical lectures and a practical approach in the laboratory in the teaching of this subject, with little integration of anatomical knowledge for application in clinical situations. However, this educational model has proved to be ineffective in serving students ${ }^{(2)}$.

The use of technological resources in the production of the educational material is a practice potentially rich in teaching and learning of subjects mediated in a virtual environment using learning objects $^{(7)}$. Also known as an instructional object, educational object or virtual object of learning, they are educational resources, created in various formats, from simple slideshows, videos or more complex resources, such as simulation, animations, text files or hypertext, used in computer-based instruction.

In this direction, there is an increase use of learning object as technology in the study of Human Anatomy, through videos and films available on Youtube $^{\circledR}$, multimedia resources such as e-book, anatomical atlas software, interactive 3D images, and complementary tutorials to favor the understanding of concepts and recognition of structures ${ }^{(8)}$.

In the teaching of the subject in the university setting, these issues are addressed in the training of nurses. Listening to the demands of students about difficulties in the scheduling and handling anatomical pieces, and ethical aspects, with questions of the real necessity of the use of this type of resource, mobilized teachers' reflection on the application of technology to drive this transformation in the teaching and learning process of the Anatomy practice.

In this context, this study was justified by the need to increase the educational process, considering the analysis derived from the teachers' perceptions and the course coordination regarding the performance and achievement of students in previous years. Faced with the new paradigms of education, besides the traditional expository methodology, it was sought to propose the inclusion of technologies, the training of nurses in the Human Anatomy subject, through the 
construction of the virtual classroom, as an object of learning, to complement the studies of Anatomy. This study aimed to describe the development of the learning object called "Disciplinary Complement of Anatomy" for the teaching and learning of the Anatomy subject.

\section{Methods}

Methodological study on the construction of the learning object for the teaching and learning of Anatomy I, called Disciplinary Complement of Anatomy, intended for students of the Bachelor of Nursing course, developed in 2014, in a private institution of higher education, located in Campinas, in the state of São Paulo, Brazil. Comprising the curricular matrix, the subject has a workload distributed in 36 hours for theoretical lectures and 36 hours of supervised practical activities in an Anatomy laboratory.

For the construction of the subject in the virtual environment, the ADDIE model was used as a reference for the instructional design ${ }^{(9)}$. The acronym ADDIE stands for Analysis, Design, Development, Implementation, Evaluation and corresponds to the different phases of the instructional design applied in construction. As a systemic model, it is comprehensive and allows an overview of the educational process, assisting in the decisions and adjustments needed to ensure the effectiveness of the educational proposal ${ }^{(9)}$.

Methodological course according to each phase: Analysis that includes the initial diagnosis of the situation, identification of the performance problems that require educational intervention, the definition of the target audience, the delineation of the schedule and the costs of the project. From discussions in regular pedagogical meetings in the teaching institution, four teachers from the theoretical fronts and laboratory practices of Human Anatomy, from different periods, morning and night, searched for solutions that contemplated new experiences for teaching-learning. Therefore, it was proposed the construction of complementary material, to be made available in a virtual environment, recommending for theoretical study, but also be used, in person or at times of study at a distance, aiming at enhancing studies on Human Anatomy.

The Design includes the definition of learning objectives, contents, sequence and structuring of the intervention. Based on the Institutional Academic Teaching Plan, the content was structured in a storyboard, using Power Point to organize the sequence of information to be addressed, delineating the logical course for the class attendance, in person and at distance. As assumptions of educational guidance, the Andragogy and Significant Learning Theory was used since they are adult students, whose learning requires meaning, in practical applicability ${ }^{(10)}$.

Development deals with the definition of teaching strategies, selection of didactic resources, tools, and technologies, in pedagogical activities. In the selection of contents for Anatomy in the virtual environment, reference sources of reliable quality and images were available on the web, which best suited the subject and the educational objectives, duly cited, according to the rights in copyright cases, although most are free content.

The Implementation consists of the execution moment of the intervention with the provision of resources and infrastructure necessary to the requirements of the educational process. The freeaccess Prezi ${ }^{\circledR}$ platform was used, since the educational institution does not yet have its own online platform.

Evaluation is a constant step in the whole process. It allows to review the construction, (re) adapt the contents and didactic resources to the degree of learning. In this study, the evaluation during the construction of the virtual class was a recursive process; as each stage was completed, sequence and contents were reviewed by the teachers, in line with the established objectives. 


\section{Results}

Among the diversity of contents to be studied, Osteomuscular Respiratory and Circulatory Systems were approached in the first moment in Anatomy I due to the provisions of the Educational Plan established in the educational institution.

In this study, the analysis of the teachers' perceptions and the course coordination, regarding the performance and achievement of the students in previous years, according to the documentary survey, indexes of grades, approval, and disapproval in Anatomy were decisive in the decision and delineation of the proposal for constructing the learning object.

The development of the virtual class resulted in the combination of elements, such as images and textual information, consisting of 392 structures (frames) in the composition of the learning object called "Disciplinary Complement of Anatomy", recommending about 4 hours per week for Online study.

In the selection of images for imaging composition, characteristics were evaluated regarding the color, size, harmony and ability of the image to transmit the desired message in the proposed context, including through semiotic analysis. Also, in the selection and composition of texts, typography was considered as facilitating the reading and understanding of contents due to the influence of these elements in readability. In a virtual environment, these aspects are essential in the construction of educational material to focus attention, avoiding distracting elements that divert attention from the desired focus, arousing interest and motivating learning.

In the proposal of the educational objectives of the virtual subject, based on the Bloom Taxonomy, the cognitive, psychomotor and affective domains were contemplated to learn terms and nomenclatures of the anatomical structures, to identify them in the accomplishment of the proposed exercises and in the ethical reflection on the study of Anatomy, in the perspective of the current reality and the use of technological resources.
In the implementation of the platform Prezi, with good portability, allows access to the virtual subject in different browsers and mobile devices. It was shown a suitable virtual environment, allowing the insertion of the hyperlink, video, and audio, as variants of stimuli for learning. In production, the financial costs of the project were low because the platform has free access and the teachers were the developers of the learning object. As an additional resource, the virtual environment allows visualizing access indexes, length of stay and keeping up with students' regularity of entry, favoring the school management of the online subject.

After the construction, the virtual class was presented to four teachers, two in the morning and two in the night, who worked on theoreticalpractical activities related to morphological sciences, experienced about the content covered in Anatomy. They provided support with bibliographic adjustments and better image choices for presentation. The Coordinator of the course approved the construction, considering that the class could be made available to the students of the course, without further suggestions or modifications.

The virtual class will be available later to the students, when then, it is intended to ask the users also to evaluate the learning object. Considering that at the end of each term, at the end of the course, the evaluation of learning is planned, the possibilities of evaluation, complementary to the virtual subject, are extended to verify the potential of learning with this tool.

\section{Discussion}

Before the systematization used in the construction of the virtual subject, considering the steps of the ADDIE model, the steps related to analysis, design, development and implementation were fulfilled. The evaluation of the learning object by users, using the Learning Object Review Instrument, is envisaged as an internationally established 
instrument ${ }^{(11)}$. The development of the virtual complement of the subject was set in a collective construction process, according to the previous perceptions of the participants, teachers, and students, from which the discussion about new ways of teaching in Anatomy and possibilities of using technology was started. The collaboration of the subjects in the construction integrates knowledge and allows greater effectiveness in educational planning ${ }^{(10)}$. As books and atlases support the learning of terms, morphology, location and function of structures, there are several technological resources that can also be applied in teaching anatomy to facilitate understanding ${ }^{(2)}$. The global trend in the use of technologies in education prevails in various parts of the world, signaling the importance of digital resources for research and training, including in Nursing. National research indicates an existing gap regarding the development and use of technologies in Nursing education, especially in the North and Northeast regions ${ }^{(12)}$.

The adoption of these innovative resources for the teaching and learning process in the area of health sciences allows interdisciplinary, through the integration of contents with other areas of knowledge, minimizing fragmentation between subjects and enables active, participatory and self-directed learning. Thus, the student becomes the articulator of his decisions in the process of construction and reconstruction of knowledge, with multiple possibilities to recognize the gaps of his learning(13).

Technology can be used in and outside the classroom, not just as an object of support for teaching ${ }^{(14)}$. It can be used in the modalities of face-toface, distance or blended learning, providing valuable opportunities to learn the content in an interactive way $^{(15)}$.

Considering that the study of Anatomy is an essential subject in the area of health sciences, a precursor for learning, among others, Physiology and Pathology ${ }^{(4)}$, the object produced in this study can be (re) used in various educational proposals, courses,
Face-to-face, hybrid or online classes, promoting interdisciplinary in teaching and learning.

The educational proposal was configured as an alternative, different from classroom, to facilitate access to content for review and improvement in the subjects ${ }^{(16)}$, including the difficulty of accessing the students to the laboratories, outside the class period, in the incompatibility for conciliate schedules available, due to the profile of students who are also workers. They are responses to the dynamism and constant transformations of the world, society, political, economic and cultural scenario and the changes in the profile of the student, as a digital native, and of the teacher, sometimes still in the figure of the digital immigrant.

In the new generation, as digital natives, students are increasingly connected with each other and with the digital world, in the natural approach to technology. When instigated in active participation, they seek to interact, participate, rather than simply listen and observe, revealing another way of learning based on the search for knowledge, group learning and exploration of the environment or the situation proposed.

In the reflection of this profile, the selection of teaching strategies requires alignment with the characteristics of the learner, whose attention to the study is stimulated by dynamic means such as videos, media, images, about the less dynamic reading of text or lecture. These characteristics are in opposition to the generation of digital immigrants, coming from a culture of passivity in the reception of the information, they strive in the appropriation of the technological knowledge and management of the digital resources. When teachers are included in this profile, reflection on the need to develop skills and digital fluency minimizes discrepancies, proposing strategies that are coherent with the profile of students ${ }^{(17)}$.

In the study of Anatomy, online learning allows reviewing and resuming content as often as necessary, from learning "doing", for the motivation and 
immediate valuation of the constructed knowledge. When teachers conduct the subject objectively, adapting the teaching of Anatomy to the needs of the student and the course, facilitating the understanding of the applicability of knowledge, as the practice of the profession, providing opportunities for the student to give greater meaning to learning ${ }^{(18)}$.

These aspects belong to the adult student, who, from the andragogical perspective, recognizes himself as independent, seeking to take advantage of previous experiences as previous knowledge that act as anchors for meaningful learning ${ }^{(19)}$.

Andragogy is about adult education, it is student-centered, independent, self-managed. It considers that adult learning is motivated by the practical application of knowledge, when useful in facing personal and professional challenges. Taking advantage of accumulated experiences and giving meaning to learning are fundamental principles in the adult teaching and learning process ${ }^{(9)}$.

In addition to considering the target audience in the design of educational proposals, planning, content organization, and selection of activities for effective instruction are closely related to instructional design, as a process for identifying a learning problem, designing, implementing, and evaluating the solution to this problem ${ }^{(9)}$.

The ADDIE model was adequate for the construction of educational material, with special attention to the conceptions adopted, based on the andragogical principles of adult learning, in a significant way. This instructional design provides input for decision-making by determining to whom, what, when, where, why and how the learning program will be structured ${ }^{(9)}$.

The Prezi ${ }^{\circledR}$ platform enabled to build the learning object and make it available in the virtual environment. It was set up in a virtual learning environment suitable for educational purposes. The virtual environment is the space that relies on systems for the development and management of virtual courses. They also have school management resources to register users and courses, record learners' information and provide reports, such as those related to the frequency of access, length of stay and monitoring of the activities carried out ${ }^{(14)}$.

It favored accessibility to developers and users, as it presented low complexity system configuration and installation requirements, reduced final cost of production, management of the planning process and later online monitoring of student participation and performance.

Prezi ${ }^{\circledR}$ helps in the integration and organization of knowledge, in the structuring of thinking, in communication skills, allowing the construction of the mental map by the students, with visual emphasis, interrelating ideas and contents. It has the potential to provide students with an engaging and stimulating educational experience. However, the effectiveness of the platform depends on the teacher's familiarization with the software ${ }^{(12)}$.

The virtual class developed offers ease of access by the user, and can be used both in face-toface and distance learning, online or offline and in different browsers and mobile devices. The Prezi ${ }^{\circledR}$ platform allows presentations with approximation and distance of images and textual information, combining virtual objects with depth effects, based on zooming presentations». It gives greater dynamicity and flexibility in content presentations, with the possibility of displaying general information on a single screen and at the same time focusing on details in an interactive way, with the advantage of associating texts, images, videos, PDF files and links ${ }^{(14)}$.

In the construction of the virtual class, as an object of learning, it is necessary to align with the educational objectives, understood as the goals to be achieved in the educational process. According to the Bloom Taxonomy, as a tool to facilitate the processes of knowledge development and planning, structuring and control of learning objectives, the objectives are classified in cognitive, affective and psychomotor 
domains, so that the selection of action verbs has relationship with the definition of the student's knowledge, skills and abilities and not only with a focus on content ${ }^{(20)}$.

In education, deciding and defining these goals implies structuring the teaching and learning process, allowing for changes in thoughts, actions and behaviors. The intentionality of the educator is expressed in this structuring, as a result of careful planning; explaining the objectives favors the achievement of results, since students will know in advance what is expected of them and how they can continue along the educational path, to build knowledge and skills training appropriate to the professional profile, in effective and lasting learning ${ }^{(20)}$.

\section{Conclusion}

The virtual class is an object of learning developed for complementation in the teaching of Human Anatomy, to be used in the teaching and learning process as a face-to-face or distance learning resource. It was set up in an innovative strategy that enables autonomy in learning and management of technologies in the educational process, articulating the approach of ethical issues in the study of Anatomy throughout the student's training. It can be used in other areas of knowledge allows interdisciplinarity and comprehensiveness of knowledge. At first, it was conceived for teaching in Nursing, but it could be applied in the training of other health professionals, in the permanent education and educational actions for orientation of the patient, the user of health services and relatives.

\section{Collaborations}

Ribeiro RL contributed in the design and structuring of the project. Masson VA, Hipolito MCV, Tobase L, and Tomazini EAS contributed writing and critically relevant review of intellectual content. Peres HHC contributed in the final approval of the version to be published.

\section{References}

1. Ministério da Educação (BR). Resolução do Conselho Nacional de Educação/Câmara de Educação Superior no 3, de 7 de novembro de 2001. Dispõe sobre as diretrizes curriculares nacionais para o curso de graduação em enfermagem. Brasília: Ministério da Educação; 2001.

2. Salbego C, Oliveira EMD, Silva MAR, Bugança PR. Percepções acadêmicas sobre o ensino e a aprendizagem em anatomia humana. Rev Bras Educ Med. 2015; 39(1):23-31.

3. Oliveira JS, Furtado F. What factors influence the approval ratings in the discipline of human anatomy. Rev Bras Educ Méd. 2015; 39(4):57485.

4. Ministério da Justiça (BR). Lei Federal № 8.501, de 30 novembro de 1992. Dispõe sobre a utilização de cadáver não reclamado, para fins de estudo ou pesquisas científicas e dá outras providências. Brasília: Ministério da Justiça; 1992.

5. Tabaac B, Goldberg G, Alvarez L, Amin M, ShupeRicksecker K, Gomez F. Bacteria detected on surfaces of formalin fixed anatomy cadavers. Ital J Anat Embryol. 2013; 18 (1):1-5.

6. Pfrimer GA, Abreu T, Vieira VS, Soares NP, AversiFerreira RAGMF, Gratão LHA, et al. Historic and teaching aspects of anatomy and cebus genus role in contemporary anatomy. Int J Morphol. 2012; 30(2):607-12.

7. Braga JC. Objetos de aprendizagem: introdução e fundamentos. Santo André: UFABC; 2014.

8. Lewis TL, Burnett B, Tunstall RG, Abrahams $\mathrm{PH}$. Complementing anatomy education using three-dimensional anatomy mobile software applications on tablet computers. Clin Anat. 2014; 27(3):313-20.

9. Gava TBS, Nobre IAM, Sondermamnn DVC. Using ADDIE model in the collaborative construction of subjects in distance education. Inform Educ Teor Prat. 2014; 17(1):111-24.

10. Sousa ATO, Formiga NS, Oliveira SHS, Costa MML, Soares MJGO. Using the theory of meaningful learning in nursing education. Rev Bras Enferm. 2015; 68(4):713-22. 
11. Nesbit JC, Jerry LI, Leacok TL. Web-based tools for collaborative evaluation of learning resources. J Syst Cybern Inform [Internet]. [cited 2016 sept 6];3(5):101-12. Available from: http://www.iiisci. org/journal/cv\$/sci/pdfs/p843017.pdf

12. Salvador PTCO, Rodrigues CCFM, Lima KYN, Alves KYA, Santos VEP. Use and development of teaching technologies presented in nursing research. Rev Rene. 2015; 16(3):442-50.

13. Duffy RM, Guerandel A, Casey P, Malone K, Kelly BD. Experiences of using Prezi in psychiatry teaching. Acad Psychiatr [Internet]. 2015 [cited 2016 Sept 6];39:615-9. Available from: http:// link.springer.com/article/10.1007/s40596-0140204-x

14. Trotta T, Spinillo CG. Technologies in the learning of Human Anatomy: possible contributions to the teaching of medicine. Rev Bras Design Inform [Internet]. 2014; [citado 2016 set 22];11(1):1-20. Disponível em: https://www.infodesign.org.br/ infodesign/article/view/214/172

15. Valente JA. Blended learning and changes in higher education: the inverted classroom proposal. Educar Rev [Internet]. 2014 [citado 2016 Set 21];(4):79-97. Disponível em http://www.scielo. br/pdf/er/nspe4/0101-4358-er-esp-04-00079. pdf
16. Boechat JCS, Gama Filho RV, Sales EC, Silva MA, Manhães FC. Um estudo sobre abordagens didático-pedagógicas no ensino da anatomia humana. Rev Cient Inter [Internet]. 2016 [citado 2016 set 6];11(1/3):42-55. Disponível em: http:// www2.interscienceplace.org/isp/index.php/isp/ article/view/472/348

17. Garcia MF, Silva D, Riedo CRF. Formação de professores a distância: o que pensam os tutores? Rev Ibero-Am Estud Educ. 2015; 10(1):67-82.

18. Piazza BL, Chassot AL. Anatomia humana, uma disciplina que causa evasão e exclusão: quando a hipótese principal não se confirma. Rev Bras Ci Mov. 2012;14(28):45-59.

19. Moreira MA. Aprendizagem significativa: a teoria e textos complementares. São Paulo: LF; 2012.

20. Costa RD, Lima RW, Silva TR, Fernandes DK. Classificação cognitiva das atividades avaliativas utilizadas nos ambientes virtuais de aprendizagem com base na taxonomia de Bloom. Rev Inform Apl [Internet]. 2014 [citado 2016 set 6];10(1). Disponível em: http://ria.net.br/index.php/ria/ article/view/115 